\title{
In vitro immunogenicity of various native and thermally processed bovine milk proteins and their mixtures
}

\author{
Dimuthu Bogahawaththa, ${ }^{*}$ Rabia Ashraf, ${ }^{*}$ Jayani Chandrapala, † Osaana Donkor, ${ }^{*}$ and Todor Vasiljevic*1 \\ *Advanced Food Systems Research Unit, Institute of Sustainable Industries \& Liveable Cities and College of Health and Biomedicine, \\ Victoria University, Werribee campus, Victoria 3030, Australia \\ †School of Science, RMIT University, Bundoora, Victoria 3083, Australia
}

\begin{abstract}
In vitro immunogenicity of various native and thermally processed $\left(72^{\circ} \mathrm{C} / 15 \mathrm{~s}\right.$ and $\left.100^{\circ} \mathrm{C} / 30 \mathrm{~s}\right)$ bovine milk protein fractions, their mixtures, whey, and skim milk, was studied by analyzing the immune response of T helper (Th) cells in human peripheral blood mononuclear cells. The secretion of Th type cytokines induced by the protein stimulants was quantified while determining the heat-induced protein denaturation. Purified whey proteins, caseins and whey fraction, and skim milk provoked substantial immune responses at various degrees, indicating their potent immunogenicity. The protein mixtures prepared using the fractionated whey proteins with or without caseins appeared less immunogenic in both native and heat-treated forms, implying their potential of producing less immunogenic dairy products. The $100^{\circ} \mathrm{C} / 30 \mathrm{~s}$ treatment significantly altered the immunogenicity of most of the potent protein stimulants, which mostly coincided with their levels of protein denaturation. The $72^{\circ} \mathrm{C} / 15 \mathrm{~s}$ treatment caused the least protein denaturation but altered the immunogenicity of several protein stimulants notably, including heat-stable caseins and $\alpha$-lactalbumin.
\end{abstract}

Key words: bovine milk protein, thermal processing, protein denaturation, immunogenicity

\section{INTRODUCTION}

Bovine milk provides high-quality proteins to fulfil the AA requirements of humans, and usually it is the first source of foreign proteins ingested by infants in large quantities (Caira et al., 2012). However, the infant's intestinal system is insufficiently developed to

Received January 23, 2018.

Accepted June 15, 2018.

${ }^{1}$ Corresponding author: todor.vasiljevic@vu.edu.au digest bovine milk proteins, and their immune system frequently reacts to milk proteins (Caira et al., 2012). The presence of bovine milk proteins in the breast milk of lactating women and bovine milk protein-specific antibodies in the cord blood demonstrate the early exposure of neonates to bovine milk proteins (Høst et al., 1999).

Immunogenicity is the ability of a substance to elicit an immune response or capacity to provoke a detectable immune response (Bier et al., 1981; Actor, 2014). Generally, different proteins demonstrate either potent or weak immunogenicity. The molecular size and other characteristics, including the nature of AA, which make up immunogenic epitopes and the accessibility to those epitopes, contribute to immunogenic capacity of a specific protein (Bier et al., 1981). Epitopes are the portions of immunogenic molecule, mostly proteins, that can bind with the complementary sites of an antibody or T/B cells (Bogahawaththa et al., 2017a). Moreover, the immunogenicity of a protein fraction can alter when it is alone or in combination with other proteins or in the original source of protein (Cross and Gill, 2000).

Bovine milk proteins, more broadly, are immunogens (e.g., antigens and allergens), which can provoke immune response in human immune system through modulating the functions of immune cells including $\mathrm{T}$ cells or binding with antibodies such as IgG or IgE (Cross and Gill, 2000). The bovine $\beta$-LG and BSA were reported to induce the activation and proliferation of $\mathrm{T}$ helper (Th) cells in human peripheral blood mononuclear cells (PBMC) and secretion of associated cytokines, where $\beta-L G$ was more potent than BSA (Vocca et al., 2011). The PBMC from a specific group of infants (suffered from necrotizing enterocolitis) showed significantly elevated production of Th type cytokines in response to bovine $\beta$-LG and caseins, where $\beta$-LG was more immunogenic than the caseins (Chuang et al., 2009). The Th cells, including Th1 and Th2 subsets, play a key role in mediating the immune defense through the celland antibody-mediated immune response, respectively. Moreover, the balance between Th1 and Th2 type cy- 
tokines is believed to determine the appropriateness of the immune response. The overexpression of Th2 type cytokines may contribute to production of $\operatorname{IgE}$ antibodies, which can elicit an immediate allergic response, for instance classical milk protein allergy reaction, in an immunocompromised subject (Rengarajan et al., 2000; Donkor et al., 2012).

Most bovine milk proteins can potentially bind with protein-specific antibodies. The ability of protein antigens to bind with IgG antibodies is termed antigenicity, whereas binding with $\mathrm{IgE}$ antibodies mostly result in allergenicity in humans. The bovine or cow milk protein allergy is the most prevalent food allergy among infants $(2-6 \%)$. The caseins and $\beta$-LG usually act as the major allergens, whereas other milk proteins such as $\alpha$-LA, BSA, and immunoglobulins can also be involved in milk protein allergy; however, their degree of involvement differs mostly from one protein fraction to the other (Bogahawaththa et al., 2017a). It is also well established that various heat treatments applied in the thermal processing of milk in the dairy industry can potentially denature native milk proteins, including unfolding and aggregation of native structure, which could subsequently modify the immunogenic epitopes and or their accessibility leading to altered immunogenicity (Bogahawaththa et al., 2017a).

The immunogenicity of native bovine milk proteins, in terms of their ability to provoke $\mathrm{T}$ cell-mediated immune response in human, has been studied to a certain extent using some individual protein fractions (e.g., $\beta$-LG, BSA; Vocca et al., 2011) and milk protein sources (e.g., skim milk; Opatha Vithana, 2012). However, the immunogenicity of various protein mixtures (e.g., $\beta$-LG and $\alpha$-LA) appears to be unknown. Although several studies reported on the effect of thermal processing on altered antigenicity and allergenicity of bovine milk proteins (Bu et al., 2013), it is largely unknown how thermal processing affects the ability of various bovine milk proteins and their mixtures to provoke $\mathrm{T}$ cellmediated immune responses in relation to protein denaturation. Thus, the present study aimed to examine the immunogenicity (in the form of ability and capacity of provoking Th cell-mediated immune response in vitro) of various native and thermally processed bovine milk protein stimulants (at their natural concentrations), such as fractionated major proteins, their mixtures, native whey, and skim milk, using human PBMC and analyzing the secretion of associated Th type cytokines. We also expected to be able to identify possible associations between the altered immunogenicity affected by thermal processing and the level of protein denaturation.

\section{MATERIALS AND METHODS}

\section{Materials and Preparation of Protein Samples}

Skim Milk and Native Whey. Murray Goulburn Co-operative (Laverton North, Victoria, Australia) provided raw bovine milk on 2 separate occasions. Upon arrival, the raw milk was skimmed by centrifugation (Avanti J-26XP, Beckman Instrument Australia Pty. Ltd., Gladesville, New South Wales, Australia) at 3,500 $\times g$ for $20 \mathrm{~min}$ at $20^{\circ} \mathrm{C}$. An aliquot of skim milk was set aside $\left(-20^{\circ} \mathrm{C}\right)$ for further experiments (S1 in Figure 1 ), and the remaining portion of the skim milk was divided into 2 parts used to prepare the native whey and caseins separately. The outline of the steps followed for the preparation of various fractionated proteins and protein mixtures is shown in Figure 1. The $\mathrm{pH}$ of the skim milk was adjusted to 4.6 using $0.1 \mathrm{M} \mathrm{HCl}$ and then the precipitated caseins were separated from the whey by centrifugation (Avanti J-26XP centrifuge, Beckman Instrument Australia Pty Ltd.) at 30,000 $\times g$ for $2 \mathrm{~h}$ at $20^{\circ} \mathrm{C}$ as explained previously (Bogahawaththa et al., $2017 \mathrm{~b}$ ). The $\mathrm{pH}$ of the resultant whey was readjusted to 6.7 using $0.1 \mathrm{M} \mathrm{NaOH}$, which was the $\mathrm{pH}$ of the fresh raw milk. An aliquot of purified native whey was stored $\left(-20^{\circ} \mathrm{C}\right)$ for further experiments (S2 in Figure 1 ), whereas the rest was used for the fractionation of native whey proteins as per our previous work (Bogahawaththa et al., 2017b).

Fractionation of Whey Proteins. In brief, 100 $\mu \mathrm{L}$ of the native whey was injected at a time with mobile phase $(0.05 \mathrm{M}$ sodium phosphate buffer at $\mathrm{pH} 7$, including $0.3 \mathrm{M}$ sodium chloride) into a size exclusion chromatography (SEC) column (Biosep SEC-s2000, Phenomenex Australia Ply Ltd., Lane Cove West, New South Wales, Australia), which was mounted to a fast protein liquid chromatography (FPLC) system (GE Healthcare Australia Pty. Ltd., Parramatta, New South Wales, Australia). The different whey proteins, such as IgG, BSA, $\beta$-LG, and $\alpha$-LA, were eluted at different retention times with mobile phase and collected separately using a Frac-950 fraction collector (GE Healthcare Australia Pty. Ltd.). An RVC 2-18 rotational vacuum concentrator (John Morris Scientific, Deepdene, Victoria, Australia) was then used to concentrate the fractionated proteins by evaporating the mobile phase at $30^{\circ} \mathrm{C}$.

Caseins. The other portion of skim milk was used to separate the caseins from the whey by ultracentrifugation (Beckman L-70 ultracentrifuge, Beckman Instrument Australia Pty Ltd.) at 100,000 $\times g$ for $1 \mathrm{~h}$ at $22^{\circ} \mathrm{C}$ without adjusting the $\mathrm{pH}$ (O'Mahony and Fox, 


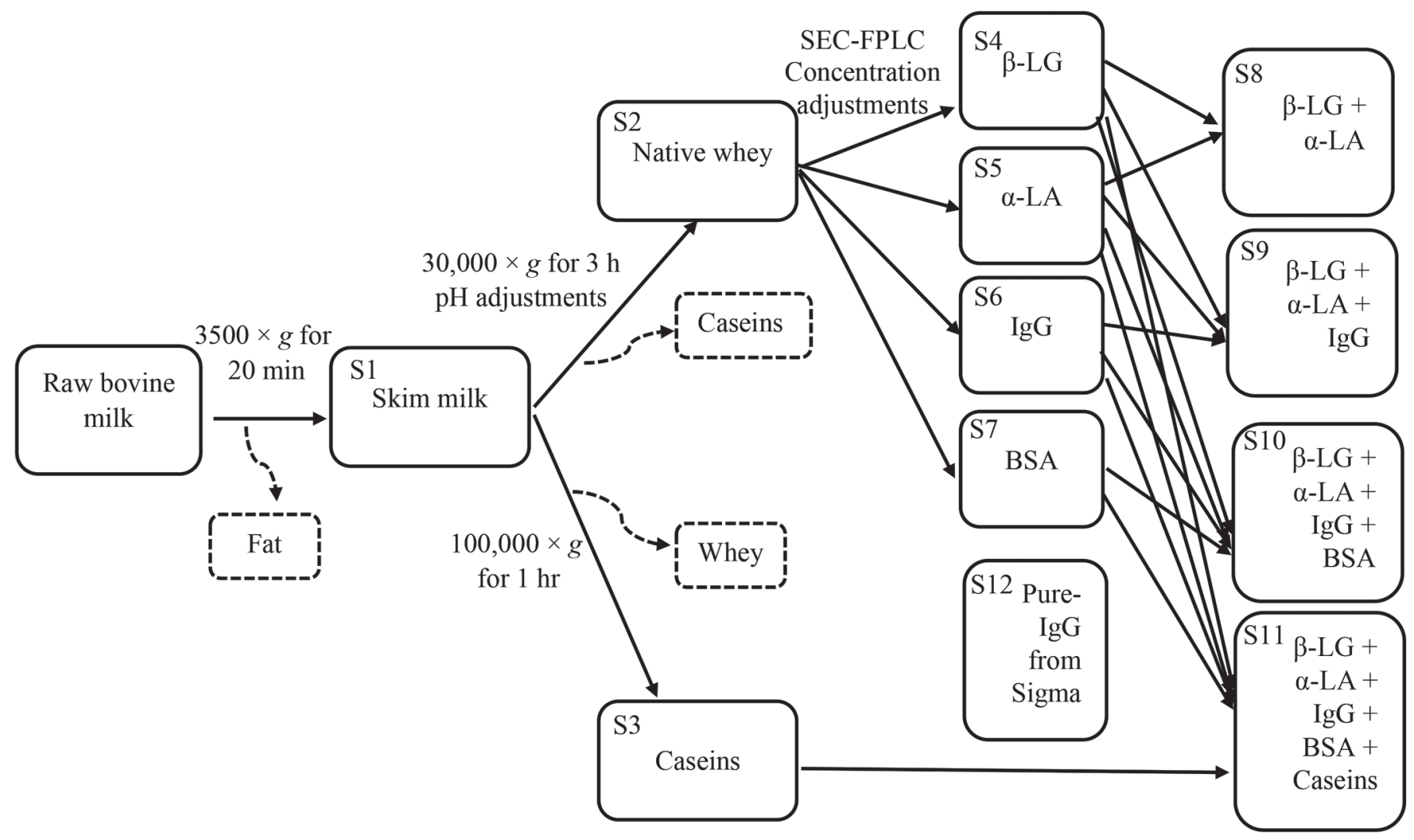

Figure 1. Outline of the steps followed for the fractionation of various bovine milk proteins and preparation of the samples (S1-12). SECFPLC = size exclusion chromatography fast protein liquid chromatography; Sigma = Sigma-Aldrich, St. Louis, MO.

2013). The casein pellet was removed from the centrifuge tube followed by 2 washing steps $(4,000 \times g$ for 10 min at $22^{\circ} \mathrm{C}$ ) with simulated milk ultrafiltrate (SMUF; Rosmaninho and Melo, 2006) and then resuspended in SMUF with continuous stirring for $48 \mathrm{~h}$ at $4^{\circ} \mathrm{C}$.

Preparation of Protein Samples. The 11 protein samples were then prepared including individual proteins alone ( 5 samples, S3-7: caseins, $\beta-\mathrm{LG}$, $\alpha-\mathrm{LA}$, IgG, and BSA), by mixing different whey protein fractions together based on the descending order of their concentration in milk (3 samples, S8-10: $\beta-\mathrm{LG}+\alpha-\mathrm{LA}, \beta-\mathrm{LG}$ $+\alpha-\mathrm{LA}+\mathrm{IgG}$, and $\beta-\mathrm{LG}+\alpha-\mathrm{LA}+\mathrm{IgG}+\mathrm{BSA}), \mathrm{a}$ mixture of caseins and 4 different whey protein fractions (1 sample, S11: caseins $+\beta-\mathrm{LG}+\alpha-\mathrm{LA}+\mathrm{IgG}+\mathrm{BSA})$, and the native whey and skim milk (2 samples, S1-2). The concentration of all the individual protein samples and protein mixtures were already readjusted using SMUF to their corresponding concentrations in skim milk, caseins, $\beta-\mathrm{LG}, \alpha-\mathrm{LA}, \mathrm{IgG}$, and BSA at 2.6, 0.32, $0.12,0.08$, and $0.04 \%$ (wt/wt), respectively (Dupont et al., 2013), as described previously (Bogahawaththa et al., 2017b). However, the IgG sample fractionated from the native whey was found to contain some BSA $(\sim 20 \%$ of the total IgG quantified by SDS-PAGE). Thus, the purified bovine IgG was purchased (Sigma-Aldrich, St. Louis, MO) and prepared with another pure IgG sample $0.08 \%$ (wt/wt) in SMUF, making the total number of samples 12 (S12 in Figure 1).

\section{Treatment of Samples}

All of the samples (12) were divided into 3 aliquots. One aliquot was the control and the other 2 aliquots were subjected to 2 heat treatments separately. The 2 heat treatments applied were $72^{\circ} \mathrm{C} / 15 \mathrm{~s}$ and $100^{\circ} \mathrm{C} / 30$ s. The $72^{\circ} \mathrm{C} / 15 \mathrm{~s}$ is considered HTST, and the effect of $100^{\circ} \mathrm{C} / 30 \mathrm{~s}$ treatment on the level of denaturation of $\beta$-LG in skim is reported to be comparable to UHT processing (Dannenberg and Kessler, 1988). Both treatments were performed in a CS/CR rheometer (MCR 301, Anton Paar GmbH, Ostfildern, Germany), as previously described (Bogahawaththa et al., 2017b), under a constant shear $\left(1,000 \mathrm{~s}^{-1}\right)$ and pressure $(\sim 250 \mathrm{kPa})$.

\section{Fourier Transform Infrared Spectroscopy}

Soon after performing each treatment, all the samples including controls were analyzed by a PerkinElmer 
Frontier Fourier Transform Infrared (FTIR) spectrometer (PerkinElmer, Waltham, MA) with a combined software of IR Solution (version 1.40, Shimadzu Corporation, Kyoto, Japan), as previously described (Bogahawaththa et al., 2017b). The samples spectra (range $4,000-600 \mathrm{~cm}^{-1}$ ) were obtained in the absorbance mode by subtracting the background. With the aid of the software, the second derivative of every spectrum was obtained to enhance the resolution. The peaks, which corresponded to the protein secondary structure, were studied within broad amide I region $\left(1,600-1700 \mathrm{~cm}^{-1}\right)$.

\section{SDS-PAGE}

Both nonreducing and reducing SDS-PAGE were performed as explained previously (Bogahawaththa et al., 2017b) for all treated and control samples, which were already mixed with SDS sample buffer $(100 \mu \mathrm{L}$ of sample in $1 \mathrm{~mL}$ of sample buffer). $\beta$-Mercaptoethanol was used to reduce the covalent bonds for reducing SDS-PAGE. Commercial whey proteins $(\beta-L G, \alpha-L A$, $\mathrm{IgG}$, and BSA) recommended for electrophoresis and the broad-range prestained SDS-PAGE standards (SeeBlue Plus2 Pre-stained Protein Standard, Thermo Fisher Scientific, Scoresby, VIC, Australia) were used as protein standards and molecular weight markers, respectively. The gel images were captured by Image Lab 5.1 software (Bio-Rad Laboratories, Galesville, NSW, Australia).

\section{Isolation of Human PBMC}

Human PBMC are widely used to investigate the effect of food bioactives on immune cells in vitro (Eriksen et al., 2008; Kleiveland, 2015). Furthermore, the use of PBMC has been recommended as an effective method, in comparison to the use of $\mathrm{T}$ cell lines or clones, for studying the immune response of human $\mathrm{T}$ cells in response to bovine milk proteins (Vocca et al., 2011). The ethics application (ID: HRE16-058) for the use of human PBMC in the current study was accepted by the Victoria University Human Research Ethics Committee.

The PBMC were isolated from buffy coats obtained from healthy individuals (Australian Red Cross Blood Services, Melbourne, Australia) following an established method in our laboratory (Donkor et al., 2012; Bogahawaththa et al., 2018) with some modifications. Briefly, about $60 \mathrm{~mL}$ of buffy coats were diluted with $1 \times$ PBS (1:2 volume ratio) and layered gently on Ficoll-Paque Plus (GE Healthcare). After centrifugation $(400 \times g$ for 30 min at $18^{\circ} \mathrm{C}$ with no break; Sorvall-RT7 centrifuge, DuPont, Newtown, CT), the PBMC layer was collected and immediately washed with RPMI-1640 (Sigma-
Aldrich, Castle Hill, New South Wales, Australia) at $400 \times g$ for $10 \mathrm{~min}$ at $18^{\circ} \mathrm{C}$ with half break. After 2 more washing steps $\left(250 \times g\right.$ for 10 min at $4^{\circ} \mathrm{C}$ with half brake) with RPMI-1640, cells were adjusted to $2.5 \times 10^{7}$ cells $/ \mathrm{mL}$ in the recovery cell culture freezing medium (Thermo Fisher Scientific Australia Pty Ltd.) and stored in liquid nitrogen until use.

\section{Stimulation of PBMC}

The stimulation of PBMC was performed as previously reported (Tafaro et al., 2007; Bogahawaththa et al., 2018) with some modifications. After thawing and removing of cells from freezing medium, the cells were resuspended in RPMI-1640 supplemented with $10 \%$ fetal bovine serum, qualified and heat inactivated (Thermo Fisher Scientific Australia Pty Ltd.), and antibiotic-antimycotic solution (Sigma-Aldrich) at $3 \times$ $10^{6}$ cells $/ \mathrm{mL}$. The stimulation of PBMC was conducted in several 24-well flat-bottomed polystyrene microtiter plates with final concentration of $1 \times 10^{6}$ cells $/ \mathrm{mL}$ in the presence of different protein stimulants $(100 \mu \mathrm{L} /$ $\mathrm{mL}$ ) at $37^{\circ} \mathrm{C}$ in $5 \% \mathrm{CO}_{2}$ for $96 \mathrm{~h}$ of incubation. Lipopolysaccharide from Escherichia coli O111:B4 (SigmaAldrich) was used to stimulate PBMC at the concentration of exactly $1 \mu \mathrm{g} / \mathrm{mL}$ as a positive control, whereas unstimulated PBMC in RPMI-1640 were also tested to determine the basal cytokine production. Supernatants of all the wells were collected by centrifugation (at 400 $\times g$ for $10 \mathrm{~min}$ at $18^{\circ} \mathrm{C}$ ) after the incubation period $(96 \mathrm{~h})$ and stored at $-20^{\circ} \mathrm{C}$ until the cytokines were quantified.

\section{Cytokine Assays}

An ELISA (Thermo Fisher Scientific Australia Pty Ltd.) was used to determine the cytokine concentrations of the supernatants including IL-4, IL-10, IL-12 (p70), IFN- $\gamma$, and IL-17A. The assays were performed according to the manufacturer's instructions (https:// www.thermofisher.com/elisa/product/).

\section{Statistical Analysis}

All the experiments were replicated by obtaining 2 batches of raw bovine milk, leaving a gap of $2 \mathrm{wk}$. All the samples were also subsampled to obtain at least 4 independent observations $(\mathrm{n} \geq 4)$. The results were analyzed as a randomized split plot design with protein stimulants as the main plot and heat treatment as a subplot using a General Linear Model of SAS statistical program. The level of significance was preset at $P \leq$ 0.05. Tukey's Studentized Range (HSD) test was used for multiple comparisons of means of cytokines secre- 
tion. The mean of at least 4 independent observations $(4 \geq n)$ was considered for comparison purposes.

\section{RESULTS AND DISCUSSION}

\section{In Vitro Immunogenicity of Bovine Protein Fractions, Whey, and Skim Milk}

The bovine milk proteins are capable of provoking protein-specific Th cell responses in the human subjects regardless of health or milk protein sensitivity (Schade et al., 2000; Vocca et al., 2011). The T cells are believed to control the isotype switching of antigen-specific B cells to IgE, which can lead to initiation of allergic reaction as well as induction of the tolerance (Ruiter et al., 2006). In vitro immunogenicity of various bovine milk protein stimulants was studied based on the response of Th cells, including Th1, Th2, and Th17, in human PBMC by analyzing the secretion of associated cytokines. These results could be linked to immune responses induced by proteins including potential allergenicity instead of testing in vitro antigenicity by the ELISA technique as in many studies (Kleber et al., 2004; Rahaman et al., 2015). The protein antigens mostly bind with IgG antibodies (antigenicity) in every individual regardless of their sensitivity to these proteins (Abbas et al., 2014). In addition, analysis of antigenicity does not provide specific information about the nature of immune response elicited, which mainly governs the reaction of human body to a particular protein (Abbas et al., 2014). Furthermore, due to ethical reasons and a greater risk of pathogen presence, the controlled human studies (in vivo) have not been conducted yet (Perdijk et al., 2018) to establish how native proteins or raw milk modulate the human immune system differently in comparison to those of heat-treated proteins. Thus, the in vitro method would be useful to generate background information for conducting in vivo human studies in the future that would potentially examine the inverse association between consumption of raw milk and development of allergy and asthma (Loss et al., 2011).

Out of 5 cytokines quantified, IFN- $\gamma$, IL-4, and IL-17 are the signature-cytokines of Th1, Th2, and Th17, respectively (Raphael et al., 2015). Furthermore, expression of IL-12 (p70) and IL-10 were also quantified in relation to Th1 and Th2 cytokines, respectively (Raphael et al., 2015); however, the production of IL-4 and IL-12 (p70) was not at a detectable level in response to all the protein stimulants quantified by ELISA. Comparably, previous studies also did not detect IL-4, which is considered to elicit IgE-mediated allergy, even when the PBMC from milk-allergic subjects were stimulated with various bovine milk proteins (Benlounes et al., 1996; Vocca et al., 2011). The other 3 types of cytokines, such as IFN- $\gamma$, IL-10, and IL-17A, were detected in the supernatants of PBMC at various levels in response to all 12 protein stimulants, except IFN- $\gamma$ in the supernatant stimulated by BSA, as shown in Table 1 .

In terms of Th1 or Th2 cytokines (IFN- $\gamma$ or IL-10), only 5 different protein stimulants, such as skim milk, native whey, caseins, $\alpha$-LA, and pure-IgG, were able to stimulate significantly $(P<0.05)$ higher mean cytokine production in comparison to the basal cytokine concentration (RPMI). The expression of IL-10 (42.2 $\mathrm{pg} / \mathrm{mL}$ ) in response to $\beta-\mathrm{LG}$ was also substantially higher than the respective basal cytokine production. The mean cytokine concentrations of the unstimulated

Table 1. Cytokine profile secreted by human peripheral blood mononuclear cells (PBMC) in response to various milk protein stimulants and controls ${ }^{1}$

\begin{tabular}{|c|c|c|c|}
\hline \multirow[b]{2}{*}{ Stimulant } & \multicolumn{3}{|c|}{ Cytokine concentration $(\mathrm{pg} / \mathrm{mL})$} \\
\hline & IL-10 & IFN- $\gamma$ & IL-17A \\
\hline $\begin{array}{l}\text { LPS (positive control) } \\
\text { IgG (pure-IgG) } \\
\text { Caseins } \\
\alpha \text {-LA } \\
\text { Skim milk } \\
\text { Native whey } \\
\beta \text {-LG } \\
\beta-L G+\alpha-L A+\text { Ig }+ \text { BSA } \\
\text { RPMI (basal cytokine level) } \\
\text { IgG (contains } 20 \% \text { of BSA) } \\
\text { Caseins }+\beta-L G+\alpha-L A+\text { Ig }+ \text { BSA } \\
\beta-L G+\alpha-L A \\
\text { BSA } \\
\beta-L G+\alpha-L A+\text { IgG }\end{array}$ & $\begin{array}{l}309.4( \pm 19.5)^{\mathrm{A}} \\
298.4( \pm 8.2)^{\mathrm{AB}} \\
269.9( \pm 4.1)^{\mathrm{B}} \\
268.6( \pm 14.4)^{\mathrm{B}} \\
179.8( \pm 4.5)^{\mathrm{C}} \\
136.8( \pm 4.8)^{\mathrm{D}} \\
42.2( \pm 15.9)^{\mathrm{E}} \\
20.8( \pm 1.2)^{\mathrm{EF}} \\
18.5( \pm 0.2)^{\mathrm{EF}} \\
13.8( \pm 2.6)^{\mathrm{EF}} \\
13.2( \pm 5.2)^{\mathrm{EF}} \\
11.5( \pm 2.9)^{\mathrm{EF}} \\
11.3( \pm 0)^{\mathrm{E}} \\
5.0( \pm 1.4)^{\mathrm{F}}\end{array}$ & $\begin{array}{r}627.4( \pm 56.4)^{\mathrm{A}} \\
384.2( \pm 12.2)^{\mathrm{B}} \\
115.0( \pm 11.5)^{\mathrm{D}} \\
216.6( \pm 4.9)^{\mathrm{C}} \\
46.8( \pm 0.2)^{\mathrm{E}} \\
12.7( \pm 2.5)^{\mathrm{E}} \\
4.1( \pm 0.9)^{\mathrm{E}} \\
3.2( \pm 2.6)^{\mathrm{E}} \\
32.4( \pm 3.3)^{\mathrm{E}} \\
1.5( \pm 0.1)^{\mathrm{E}} \\
12.1( \pm 0.6)^{\mathrm{E}} \\
1.0( \pm 0.5)^{\mathrm{E}} \\
0.0 \mathrm{E} \\
5.8( \pm 0.2)^{\mathrm{E}}\end{array}$ & $\begin{aligned} & 158.6( \pm 18.8)^{\mathrm{A}} \\
& 79.2( \pm 3.8)^{\mathrm{B}} \\
& 13.8( \pm 0.2)^{\mathrm{C}} \\
& 69.9( \pm 26.6)^{\mathrm{B}} \\
& 6.8( \pm 5.7)^{\mathrm{C}} \\
& 10.75( \pm 5.2)^{\mathrm{C}} \\
& 6.25( \pm 0.9)^{\mathrm{C}} \\
& 7.4( \pm 3.8)^{\mathrm{C}} \\
& 28.6( \pm 1.1)^{\mathrm{C}} \\
& 2.7( \pm 0.6)^{\mathrm{C}} \\
& 2.2( \pm 3.1)^{\mathrm{C}} \\
& 0.75( \pm 1.1)^{\mathrm{C}} \\
& 1.2( \pm 0.8)^{\mathrm{C}} \\
& 4.25( \pm 5.6)^{\mathrm{C}}\end{aligned}$ \\
\hline
\end{tabular}

\footnotetext{
${ }^{\mathrm{A}-\mathrm{F}}$ Means in the same column with different superscripts are significantly different $(P<0.05)$.

${ }^{1}$ Values are presented as the mean cytokine concentration $(\mathrm{pg} / \mathrm{mL})$ of at least 4 independent measurements $(4 \geq \mathrm{n})$ plus or minus SD.
} 
supernatant (supernatant of PBMC in RPMI medium alone) were considered the basal cytokine concentrations and were recorded at $18.5,32.4$, and $28.6 \mathrm{pg} / \mathrm{mL}$ of IL-10, IFN- $\gamma$, and IL-17A, respectively. Thus, only skim milk, native whey, caseins, $\alpha-\mathrm{LA}$, pure-IgG, and $\beta$-LG appeared to be the potent immunogens under the current experimental conditions, and were considered for further analysis.

The rest of the stimulants appeared relatively less immunogenic. They were mostly the protein mixtures prepared from the protein fractions $(\beta-\mathrm{LG}+\alpha-\mathrm{LA}$, $\beta-\mathrm{LG}+\alpha-\mathrm{LA}+\mathrm{IgG}, \beta-\mathrm{LG}+\alpha-\mathrm{LA}+\operatorname{IgG}+\mathrm{BSA}$, and caseins $+\beta-\mathrm{LG}+\alpha-\mathrm{LA}+\mathrm{IgG}+\mathrm{BSA}$ ) and the IgG containing $\sim 20 \%$ of BSA. This generated some interesting information to direct further studies toward the preparation of less immunogenic bovine milk-based products by manipulating the natural composition of the milk proteins, which are suitable for the bovine milk protein-sensitive subjects. A study reported that the modified bovine milk, which possessed the modified caseins to whey proteins ratio of 40:60 (this ratio is usually 80:20 in natural bovine milk and 40:60 in human breast milk), demonstrated potentially fewer allergic properties than the native bovine milk in a murine model of atopy (Lara-Villoslada et al., 2005). This modified casein-to-whey protein ratio is suggested to induce biochemical interactions between caseins and $\beta$-LG, which in turn facilitate the digestion of $\beta$-LG leading to reduced allergenicity. Another study suggested the possibility of producing hypoallergenic dairy products including only the heat-denatured whey proteins $\left(\geq 100^{\circ} \mathrm{C}\right)$ without any caseins (Kilshaw et al., 1982).

Cross and Gill (2000), in a review, stated that the immunogenicity and immunomodulatory properties of the individual protein fractions become more potent once they are purified from the primary protein source. On the other hand, those effects could be either diminished or remain undetectable when they are present in milk or milk products. Interestingly, in the current study, we also observed some significant $(P<0.05)$ differences between the immunogenicity of the fractionated proteins, their protein mixtures, and their protein sources (Table 1). For instance, the mean cytokine productions of IFN- $\gamma$ and IL-10 in response to $\alpha-\mathrm{LA}$ were significantly $(P<0.05)$ higher than that of $\beta-\mathrm{LG}$ $+\alpha$-LA. The PBMC stimulated by pure IgG secreted significantly higher amounts of IFN- $\gamma$ and IL-10 than the IgG containing some BSA. A significantly $(P<$ $0.05)$ higher level of IFN- $\gamma$ and IL-10 was secreted by $\mathrm{PBMC}$ in response to bovine caseins than the caseins with other 4 whey proteins (caseins $+\beta$-LG $+\alpha$-LA $+\operatorname{IgG}+\mathrm{BSA})$. On the contrary, the BSA, as a purified protein fraction, could not stimulate a substantial cytokine response in comparison to the basal cytokine levels. Vocca et al. (2011) also reported that the secretion of IFN- $\gamma$ and IL-10 by human PBMC in response to BSA was either undetectable or nonsignificant.

Although the total protein concentrations were higher in all the protein mixtures than those of individual protein stimulants discussed above, all the protein mixtures showed the diminished immunogenic capacity in comparison to the respective individual proteins. Cross and Gill (1999) reported that the modified bovine whey protein concentrate can modulate the proliferation of murine $\mathrm{T}$ and $\mathrm{B}$ cells in a dose-dependent manner (1.6 to $1.5 \mu \mathrm{g} / \mathrm{mL}$ ), where high whey protein concentrate concentrations $(\geq 0.4 \mathrm{mg} / \mathrm{mL})$ significantly suppressed both $\mathrm{T}$ and $\mathrm{B}$ cell proliferation. In contrast, in the current study, the secretion of IL-10 was significantly $(P<$ $0.05)$ greater by stimulated PBMC in response to mixture of 4 main whey protein fractions $(\beta-\mathrm{LG}+\alpha-\mathrm{LA}$ $+\mathrm{IgG}+\mathrm{BSA})$, native whey, and skim milk, in the same order, although the total protein concentration also increased in that order. This highlighted the fact that not only protein concentration, but also the nature and composition of the proteins, can possibly modulate $\mathrm{T}$ cell-mediated immune response differently.

The PBMC stimulated with pure $\operatorname{IgG}$ and $\alpha$-LA secreted substantially higher concentrations of all 3 types of cytokines than $\beta$-LG and caseins, which are considered the major milk protein antigens or allergens (Lifschitz and Szajewska, 2015). This could be ascribed to the ability of these protein fractions to modulate the proliferation or activation of lymphocytes differently (Reyes-Díaz et al., 2017) apart from their ability to bind with $\operatorname{IgG}$ or IgE antibodies. For example, the bovine $\alpha s_{1^{-}}, \beta-$, and $\kappa_{-}-\mathrm{CN}$ were capable of inhibiting the proliferative responses of the mouse lymphocytes (Otani and Hata, 1995). The immune responses of Th and B lymphocytes were more enhanced by $\alpha$-LA than caseins in mice (Bounous and Kongshavn, 1985). The substantially lower concentration of cytokines stimulated by $\beta$-LG, in comparison to pure-IgG, $\alpha$-LA, and caseins observed in our study could be attributed to the considerably lower level of proliferation of immune cells stimulated by $\beta-\mathrm{LG}$ in healthy PBMC (Vocca et al., 2011 ) and the activation of regulatory $\mathrm{T}$ cells and associated suppressive mechanisms in healthy individuals (Akdis et al., 2004) in comparison to milk-allergic subjects. This emphasized the fact that understanding not only the ability of various bovine milk proteins to bind with antibodies (IgG or $\operatorname{IgE}$ ), but also their ability to modulate the functions of human lymphocytes, would be important when developing hypoimmunogenic milk products.

Bovine milk proteins are known to induce the Th2 polarized (Th1 < Th2) immune response, leading to 
IgE-mediated milk allergy in atopic subjects (Tsitoura and Tassios, 2006). In the current study, skim milk, caseins, native whey, $\alpha$-LA, and $\beta-\mathrm{LG}$ stimulated the PBMC to secrete a substantially lower level of IFN- $\gamma$ (Th1 type cytokine) than IL-10 (Th2 type cytokine). The expression of IFN- $\gamma$ or IL-10 in response to skim milk, caseins, native whey, $\alpha-\mathrm{LA}$, and $\beta-\mathrm{LG}$ were reported as 46.8/179.8, 115.0/269.9, 12.7/136.8, $216.6 / 268.6$, and $4.1 / 42.2 \mathrm{pg} / \mathrm{mL}$, respectively. Only pure IgG stimulated the PBMC to secrete a substantially higher level of IFN- $\gamma(384.2 \mathrm{pg} / \mathrm{mL})$ than IL-10 (298.4 pg/mL). Vocca et al. (2011) observed a higher number of IL-10 producing cells in human PBMC of both milk protein allergic and healthy subjects than the IFN- $\gamma$-producing cells in response to $\beta-\mathrm{LG}$, which was in line with our results.

Only 2 protein stimulants, $\alpha-\mathrm{LA}$ and pure $\operatorname{IgG}$, were capable of inducing the PBMC to secrete significantly higher $(P<0.05)$ amounts of IL-17A, recorded at 69.9 and $79.2 \mathrm{pg} / \mathrm{mL}$, respectively, than its basal level $(28.6$ $\mathrm{pg} / \mathrm{mL}$ ). Dhuban et al. (2013) observed a significantly lower level of IL-17A production in Th17 cells of food allergic subjects than healthy controls in response to various food antigens. A trend toward negative correlation has been reported between the level of IL-17A in whole blood and sensitization to food antigens (Herberth et al., 2010). The ability of bovine IgG in stimulating the human PBMC to express substantially higher level of Th1 and Th17 type cytokines (e.g., IFN- $\gamma$ and IL-17A, respectively) in the current study hinted at its ability in mediating adverse immune responses relating to milk allergy. However, the real effects of these results on milk protein allergy can only be established through comprehensive in vivo studies in consideration of the fate of bovine milk proteins in human gastrointestinal tract and the complex interplay of immune responses in the atopic subjects.

\section{Effects of Thermal Processing on Immunogenicity of Bovine Milk Proteins in Relation to Protein Denaturation}

In the current study, 2 heat treatments $\left(72^{\circ} \mathrm{C} / 15\right.$ $\mathrm{s}$ and $100^{\circ} \mathrm{C} / 30 \mathrm{~s}$ ) were applied to all the 12 protein stimulants, whereas the untreated protein samples at room temperature $\left(\sim 20^{\circ} \mathrm{C}\right)$ were considered controls. The 6 protein stimulants, skim milk, native whey, caseins, $\beta$-LG, $\alpha$-LA, and pure IgG, which induced substantially high cytokine profiles, displayed variations in expression of cytokines depending on the different heat treatments, as shown in Figure 2-A, B, C, D and E. The remaining portion of the protein stimulants, which demonstrated relatively less immunogenic capacity, did not display substantial differences in their cytokine profiles even after heat treatments (data not shown). This indicated the potential of applying the traditional thermal methods to process those protein mixtures largely without affecting their immunogenicity.

The skim milk subjected to $100^{\circ} \mathrm{C} / 30 \mathrm{~s}$ treatment stimulated a significantly $(P<0.05)$ different cytokine profile than that of the control in terms of all 3 different cytokines (IL-10, IFN- $\gamma$, and IL-17A). However, the cytokine profile induced by $72^{\circ} \mathrm{C} / 15 \mathrm{~s}$ treated skim milk appeared mostly similar to that of the control except the lower production of IFN- $\gamma$. Comparably, the native whey subjected to $100^{\circ} \mathrm{C} / 30 \mathrm{~s}$ treatment induced the secretion of IL-10 and IL-17A significantly different than that of the control, whereas the native whey treated by $72^{\circ} \mathrm{C} / 15 \mathrm{~s}$ demonstrated an almost similar cytokine profile in comparison to its control. These results appeared to coincide with the level of protein denaturation in skim milk and whey, respectively. Our FTIR (data not shown) and SDS-PAGE results (Figure 3 ) of the current study demonstrated that the $72^{\circ} \mathrm{C} / 15 \mathrm{~s}$ treatment resulted in no or minimal denaturation of the native milk proteins. Our previous study also reported comparable results in relation to all the major whey proteins ( $\beta-\mathrm{LG}, \alpha-\mathrm{LA}, \mathrm{IgG}$, and BSA) and native whey (Bogahawaththa et al., 2017b). The mostly unchanged cytokine profiles displayed by $72^{\circ} \mathrm{C} / 15 \mathrm{~s}$ treated skim milk and whey in comparison to those of controls could be attributed to no or little denaturation of the native proteins affected by that treatment. However, the denaturation of minor whey proteins, including IgG and BSA, to a certain extent has been reported when skim milk was subjected the same treatment elsewhere (Patel et al., 2006). Moreover, other in vivo studies reported the alteration of immunogenicity of bovine milk upon processing by pasteurizing treatments such as $72^{\circ} \mathrm{C} / 15 \mathrm{~s}$ (Høst and Samuelsson, 1988) and $74^{\circ} \mathrm{C} / 15 \mathrm{~s}$ (Feng and Collins, 1999). These contradicting results in comparison to the current study could be attributed to the variations in the application of the heat treatments, including variation in heating rates and the methods used for assessing the immunogenicity.

The significantly different cytokine profiles induced by skim milk and whey, after $100^{\circ} \mathrm{C} / 30 \mathrm{~s}$ treatment in comparison to those of controls, can possibly be related to the denaturation of heat-labile milk proteins affected by that treatment. The SDS-PAGE results of the current study displayed (Figure 3 ) that $100^{\circ} \mathrm{C} / 30 \mathrm{~s}$ treatment resulted in denaturation of $\beta-\mathrm{LG}$ and further formation of the protein aggregates via covalent interactions with the contribution of other whey proteins and caseins (e.g., $\kappa-\mathrm{CN}$ ), where available. These findings on protein denaturation and aggregation agreed with the available literature (Wijayanti et al., 2014; Bogahawaththa et al., 2017b). 
The cytokine profiles stimulated by $\beta$-LG, subjected to $72^{\circ} \mathrm{C} / 15 \mathrm{~s}$ and $100^{\circ} \mathrm{C} / 30 \mathrm{~s}$ treatments, were different from its control only in terms of expressing IL-10 $(P$ $<0.05$ ). Denaturation of $\beta-\mathrm{LG}$ was not observed in our results at $72^{\circ} \mathrm{C} / 15 \mathrm{~s}$, but treatment at $100^{\circ} \mathrm{C} / 30 \mathrm{~s}$ resulted in denaturation and covalent aggregation of $\beta-L G$, as reported previously (Wijayanti et al., 2014). The pure IgG also demonstrated comparable results. At least 2 different cytokines were significantly different in the cytokine profiles induced by $72^{\circ} \mathrm{C} / 15 \mathrm{~s}$ and $100^{\circ} \mathrm{C} / 30 \mathrm{~s}$ treated samples in comparison to that of the control, whereas we found no notable denaturation of $\operatorname{IgG}$ affected by $72^{\circ} \mathrm{C} / 15 \mathrm{~s}$ treatment. On the other hand, the treatment at $100^{\circ} \mathrm{C} / 30 \mathrm{~s}$ caused denaturation and induced covalent aggregation of $\operatorname{IgG}$, as observed previously (Bogahawaththa et al., 2017b). It is thus unlikely to relate the altered cytokine profiles induced by $72^{\circ} \mathrm{C} / 15 \mathrm{~s}$ treated $\beta-\mathrm{LG}$ and pure IgG with the denaturation of the respective proteins. However, $72^{\circ} \mathrm{C}$ appeared to be a critical temperature limit, which would initiate the denaturation of IgG contributing to the altered immunogenicity ( $\mathrm{Li}$ et al., 2005). The heataggregated bovine $\operatorname{Ig} \mathrm{G}$ was previously demonstrated to have altered immunogenicity, in comparison to its native form, with stimulation of human PBMC (Kulczycki et al., 1987).

Moreover, the cytokine profiles induced by $\alpha$-LA and caseins, which were subjected to $72^{\circ} \mathrm{C} / 15 \mathrm{~s}$ and $100^{\circ} \mathrm{C} / 30 \mathrm{~s}$ treatments, were noticeably different from those of the controls. At least the expression of 2 types of cytokines were significantly different $(P<0.05)$ than the control; however, $\alpha$-LA and caseins are generally more heat-stable than other milk proteins (Wijayanti et al., 2014; Huppertz, 2016). We observed no apparent formation of covalent complexes in our SDS-PAGE results of both $\alpha-\mathrm{LA}$ and caseins, even at $100^{\circ} \mathrm{C}$ for $30 \mathrm{~s}$, but the reduction of some secondary structures in $\alpha-\mathrm{LA}$ ( $\alpha$-helix at $1,651 \mathrm{~cm}^{-1}$ and $\beta$-sheets at $1,636 \mathrm{~cm}^{-1}$ ) was observed by FTIR (data not shown), indicating some unfolding of the protein.

It is established that the heat-induced denaturation of milk proteins can modify IgG- or IgE-binding epitopes, which may result in enhanced, diminished, or unchanged antigenicity or allergenicity (Bogahawaththa et al., 2017a). In parallel, heating may modify the $\mathrm{T}$ cell-specific epitopes present in bovine milk proteins
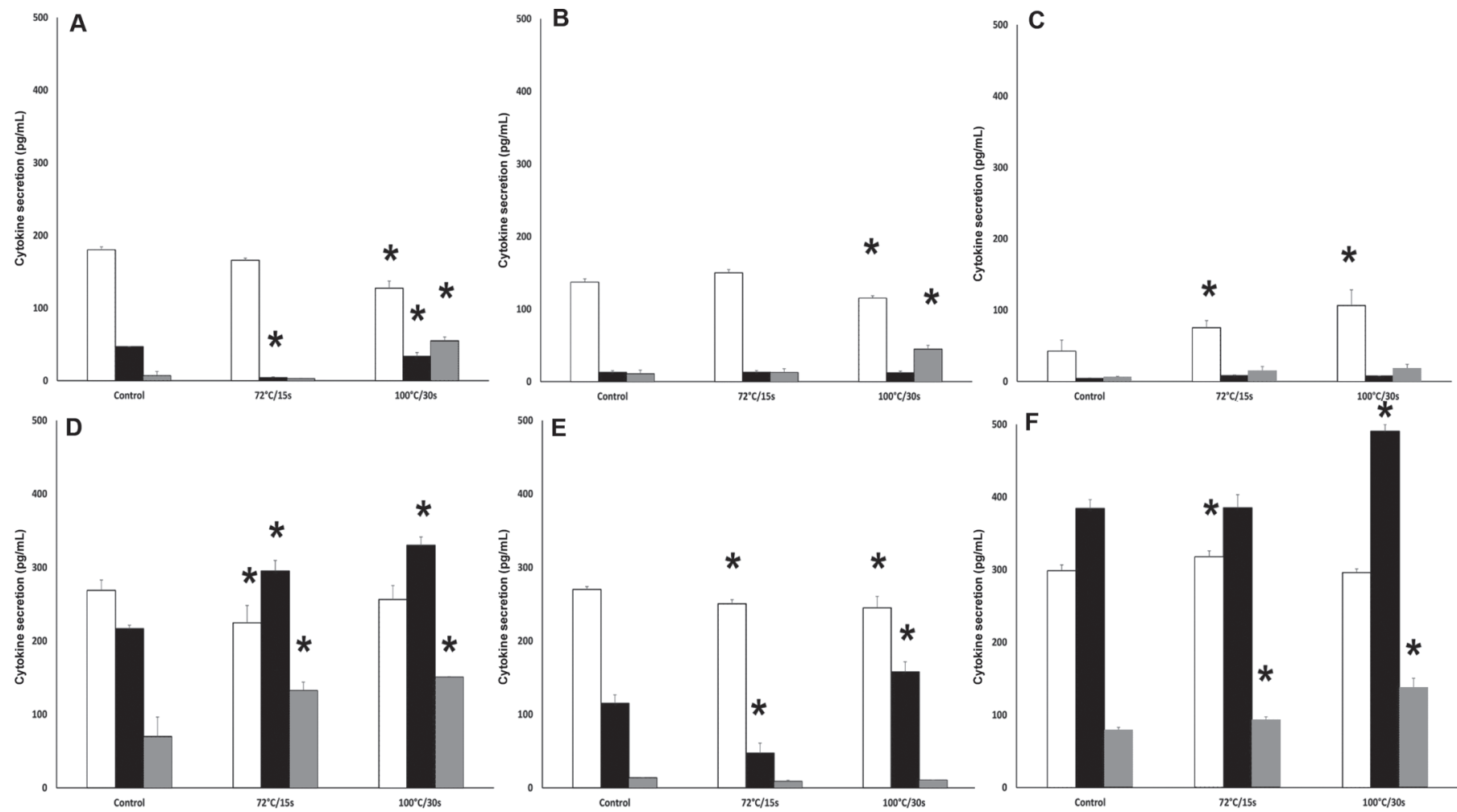

Figure 2. Production of cytokines, IL-10 (white), IFN- $\gamma$ (black), and IL-17A (gray), by human peripheral blood mononuclear cells (PBMC) stimulated by (A) skim milk, (B) native whey, (C) $\beta$-LG, (D) $\alpha-\mathrm{LA},(\mathrm{E})$ caseins, and (F) pure IgG. Control was untreated, and $72^{\circ} \mathrm{C} / 15 \mathrm{~s}$ and $100^{\circ} \mathrm{C} / 30 \mathrm{~s}$ are the 2 heat treatments applied, which appear in the same order. Data are expressed as the mean cytokine secretion $(\mathrm{pg} / \mathrm{mL})$ of at least 4 independent measurements $(4 \geq \mathrm{n})$ plus or minus SD. *Mean cytokine secretion induced by the treatment is significantly different than that of the control $(P<0.05)$. 

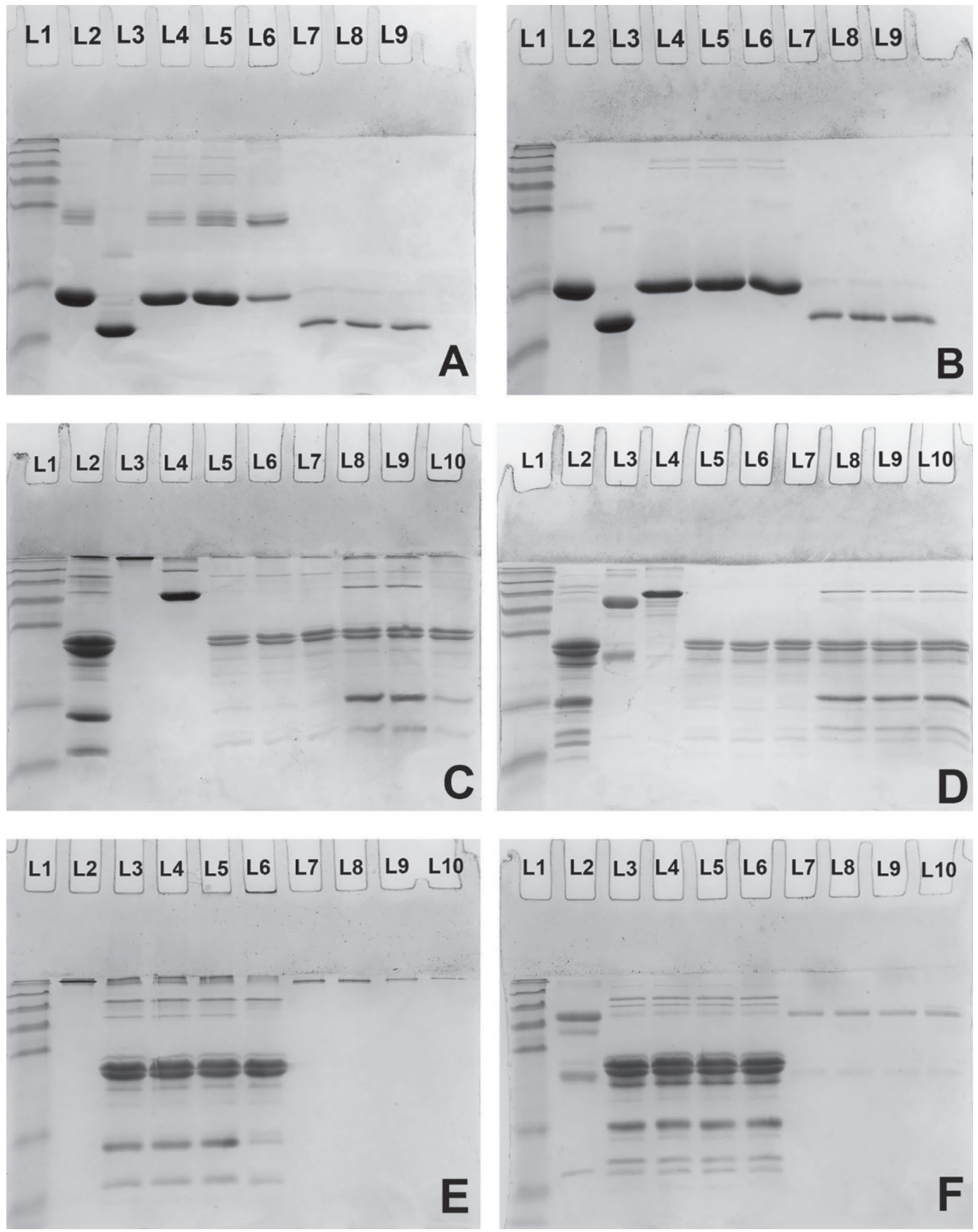

Figure 3. Nonreducing (A) and reducing (B) SDS-PAGE analysis of $\beta-\mathrm{LG}$ and $\alpha$-LA. Lanes are designated as L1 = molecular weight markers; L2 $=\beta$-LG standard; L3 $=\alpha$-LA standard; L4 $=\beta$-LG control; $\mathrm{L} 5=\beta-\mathrm{LG} 72^{\circ} \mathrm{C} / 15$ s treated; $\mathrm{L} 6=\beta-\mathrm{LG} 100^{\circ} \mathrm{C} / 30 \mathrm{~s}$ treated; $\mathrm{L} 7=\alpha-\mathrm{LA}$ control; L8 $=\alpha-\mathrm{LA} 72^{\circ} \mathrm{C} / 15 \mathrm{~s}$ treated; $\mathrm{L} 9=\alpha-\mathrm{LA} 100^{\circ} \mathrm{C} / 30 \mathrm{~s}$ treated. Nonreducing $(\mathrm{C})$ and reducing (D) SDS-PAGE analysis of caseins and caseins $+\beta-\mathrm{LG}+\alpha-\mathrm{LA}+\mathrm{IgG}+\mathrm{BSA}$. Lanes are designated as $\mathrm{L} 1=$ molecular weight markers; $\mathrm{L} 2=$ skim milk control; L3 = IgG standard; $\mathrm{L} 4=\mathrm{BSA}$ standard; $\mathrm{L} 5=$ caseins control; $\mathrm{L} 6=$ caseins $72^{\circ} \mathrm{C} / 15 \mathrm{~s}$ treated; $\mathrm{L} 7=$ caseins $100^{\circ} \mathrm{C} / 30 \mathrm{~s}$ treated; $\mathrm{L} 8=$ caseins $+\beta-\mathrm{LG}+\alpha-\mathrm{LA}+$ $\mathrm{IgG}+\mathrm{BSA}$ control; $\mathrm{L} 9=$ caseins $+\beta-\mathrm{LG}+\alpha-\mathrm{LA}+\mathrm{IgG}+\mathrm{BSA} 72^{\circ} \mathrm{C} / 15$ s treated; $\mathrm{L} 10=$ caseins $+\beta-\mathrm{LG}+\alpha-\mathrm{LA}+\mathrm{IgG}+\mathrm{BSA} 100^{\circ} \mathrm{C} / 30$ s treated. Nonreducing (E) and reducing (F) SDS-PAGE analysis of skim milk and pure-IgG. Lanes are designated as L1 = molecular weight markers; L2 $=$ IgG standard; L3 $=$ skim milk control; L4 = skim milk $72^{\circ} \mathrm{C} / 15$ s treated; L5 $=$ skim milk $80^{\circ} \mathrm{C} / 2$ min treated*; L6 $=$ skim milk $100^{\circ} \mathrm{C} / 30$ s treated; $\mathrm{L} 7=\mathrm{IgG}$ control; $\mathrm{L} 8=\mathrm{IgG} 72^{\circ} \mathrm{C} / 15$ s treated; $\mathrm{L} 9=\mathrm{IgG} 80^{\circ} \mathrm{C} / 2$ min treated $* \mathrm{~L} 10=\mathrm{IgG} 100^{\circ} \mathrm{C} / 30 \mathrm{~s}$ treated. ${ }^{*} \mathrm{The}$ treatments have not been considered for this study. 
and modulate the functions of $\mathrm{T}$ cells differently (Ruiter et al., 2006). In general, the altered immunogenicity observed in most of the protein stimulants followed by $100^{\circ} \mathrm{C} / 30 \mathrm{~s}$ treatment could be related to the effect on $\mathrm{T}$ cell epitopes, such as modifications, fragmentation, masking, unmasking, and formation of new epitopes, through the unfolding of native protein structure, interor intraprotein aggregation, and probably interactions with other nonprotein constituents (e.g., lactose). We have already reviewed the comparable findings in relation to IgG- or IgE-binding epitopes (Bogahawaththa et al., 2017a). Furthermore, Roth-Walter et al. (2008) reported that the absorption path of heat-aggregated bovine $\beta$-LG and $\alpha$-LA in intestinal epithelium was different from the path of those of the native proteins, which can modulate the functions of $\mathrm{T}$ cells differently and provoke Th2-type immune response in mice. However, further investigations are required, in consideration of digestion, absorption, and the complex interplay of immune response, to establish the associations between the protein denaturation and the alteration of immunogenicity and to elucidate how immunogenicity can alter without apparent denaturation of the proteins affected by heating.

\section{CONCLUSIONS}

Bovine skim milk, its main protein fractions (e.g., whey and caseins), and purified major whey proteins such as $\beta$-LG, $\alpha$-LA, and IgG are capable of provoking notable immune responses in human PBMC at various capacities. When 2 or more fractionated whey proteins or caseins or both are mixed together, the immunogenic capacity of those protein mixtures appear to be weak and not to be affected by thermal processing. This could be a useful strategy to produce less immunogenic dairy products from the fractionated milk proteins, suitable for people with milk protein sensitivity. The immunogenicity of bovine milk proteins appears to depend on the factors such as the nature of the protein, protein concentration, composition of the protein mixture, and the level of protein denaturation. The altered immunogenicity demonstrated by most of the potent protein stimulants subjected to $100^{\circ} \mathrm{C} / 30 \mathrm{~s}$ treatment, in comparison to their controls, appears to be associated with the level of protein denaturation, possibly due to the modifications in $\mathrm{T}$ cell epitopes. The $72^{\circ} \mathrm{C} / 15 \mathrm{~s}$ treatment did not seem to denature all the protein stimulants notably, but the immunogenicity appears substantially altered in some of the milk stimulants, including the heat-stable proteins such as $\alpha-\mathrm{LA}$ and caseins. Further studies are thus required to elucidate the effect of thermal processing on the altered immunogenicity of bovine milk proteins in relation to protein denaturation and to establish the real effects of native and thermally processed milk protein stimulants on the human immune system in vivo.

\section{ACKNOWLEDGMENTS}

The authors acknowledge the financial and technical support provided by Victoria University.

\section{REFERENCES}

Abbas, A. K., S. Pillai, and A. H. Lichtman. 2014. Basic Immunology: Functions and Disorders of the Immune System. Elsevier Health Sciences, Amsterdam, the Netherlands.

Actor, J. K. 2014. Introductory Immunology: Basic Concepts for Interdisciplinary Applications. Academic Press, San Diego, CA.

Akdis, M., J. Verhagen, A. Taylor, F. Karamloo, C. Karagiannidis, R. Crameri, S. Thunberg, G. Deniz, R. Valenta, H. Fiebig, and C. Kegel. 2004. Immune responses in healthy and allergic individuals are characterized by a fine balance between allergen-specific T regulatory 1 and T helper 2 cells. J. Exp. Med. 199:1567-1575.

Benlounes, N., C. Dupont, C. Candalh, M.-A. Blaton, N. Darmon, J.-F. Desjeux, and M. Heyman. 1996. The threshold for immune cell reactivity to milk antigens decreases in cow's milk allergy with intestinal symptoms. J. Allergy Clin. Immunol. 98:781-789.

Bier, O. G., W. D. Da Silva, D. Götze, and I. Mota. 1981. Fundamentals of Immunology. 2nd ed. Springer-Verlag, Berlin, Germany.

Bogahawaththa, D., R. Buckow, J. Chandrapala, and T. Vasiljevic. 2018. Comparison between thermal pasteurization and high pressure processing of bovine skim milk in relation to denaturation and immunogenicity of native milk proteins. Innov. Food Sci. Emerg. Technol. 47:301-308.

Bogahawaththa, D., J. Chandrapala, and T. Vasiljevic. 2017a. Modulation of milk immunogenicity by thermal processing. Int. Dairy J. 69:23-32.

Bogahawaththa, D., J. Chandrapala, and T. Vasiljevic. 2017b. Thermal denaturation of bovine immunoglobulin $\mathrm{G}$ and its association with other whey proteins. Food Hydrocoll. 72:350-357.

Bounous, G., and P. Kongshavn. 1985. Differential effect of dietary protein type on the B-cell and T-cell immune responses in mice. J. Nutr. 115:1403-1408.

Bu, G., Y. Luo, F. Chen, K. Liu, and T. Zhu. 2013. Milk processing as a tool to reduce cow's milk allergenicity: A mini-review. Dairy Sci. Technol. 93:211-223.

Caira, S., R. Pizzano, G. Picariello, G. Pinto, M. Cuollo, L. Chianese, and F. Addeo. 2012. Milk protein: Allergenicity of milk proteins. Intech, London, UK.

Chuang, S. L., P. Hayes, E. Ogundipe, M. Haddad, T. MacDonald, and J. Fell. 2009. Cow's milk protein-specific T-helper type I/II cytokine responses in infants with necrotizing enterocolitis. Pediatr. Allergy Immunol. 20:45-52.

Cross, M. L., and H. Gill. 2000. Immunomodulatory properties of milk. Br. J. Nutr. 84(Suppl. 1):S81-89.

Cross, M. L., and H. S. Gill. 1999. Modulation of immune function by a modified bovine whey protein concentrate. Immunol. Cell Biol. $77: 345-350$.

Dannenberg, F., and H. G. Kessler. 1988. Reaction kinetics of the denaturation of whey proteins in milk. J. Food Sci. 53:258-263.

Dhuban, K. B., E. d'Hennezel, M. Ben-Shoshan, C. McCusker, A. Clarke, P. Fiset, B. Mazer, and C. A. Piccirillo. 2013. Altered T helper 17 responses in children with food allergy. Int. Arch. Allergy Immunol. 162:318-322.

Donkor, O. N., M. Ravikumar, O. Proudfoot, S. L. Day, V. Apostolopoulos, G. Paukovics, T. Vasiljevic, S. L. Nutt, and H. Gill. 2012. Cytokine profile and induction of $\mathrm{T}$ helper type 17 and regulatory $\mathrm{T}$ cells by human peripheral mononuclear cells after microbial exposure. Clin. Exp. Immunol. 167:282-295. 
Dupont, D., T. Croguennec, A. Brodkorb, and R. Kouaouci. 2013. Advanced Dairy Chemistry: Quantitation of Proteins in Milk and Milk Products. Springer, Berlin, Germany.

Eriksen, E., G. Vegarud, T. Langsrud, H. Almaas, and T. Lea. 2008 Effect of milk proteins and their hydrolysates on in vitro immune responses. Small Rumin. Res. 79:29-37.

Feng, C. G., and A. M. Collins. 1999. Pasteurisation and homogenisation of milk enhances the immunogenicity of milk plasma proteins in a rat model. Food Agric. Immunol. 11:251-258.

Herberth, G., C. Daegelmann, S. Röder, H. Behrendt, U. Krämer, M. Borte, J. Heinrich, O. Herbarth, and I. Lehmann. 2010. IL-17E but not IL-17A is associated with allergic sensitization: Results from the LISA study. Pediatr. Allergy Immunol. 21:1086-1090.

Høst, A., B. Koletzko, S. Dreborg, A. Muraro, U. Wahn, P. Aggett, J. L. Bresson, O. Hernell, H. Lafeber, K. F. Michaelsen, and J. L. Micheli. 1999. Dietary products used in infants for treatment and prevention of food allergy. Arch. Dis. Child. 81:80-84.

Høst, A., and E. G. Samuelsson. 1988. Allergic reactions to raw, pasteurized, and homogenized/pasteurized cow milk: A comparison. Allergy 43:113-118.

Huppertz, T. 2016. Advanced Dairy Chemistry: Heat Stability of milk. Springer, Berlin, Germany.

Kilshaw, P. J., L. Heppell, and J. Ford. 1982. Effects of heat treatment of cow's milk and whey on the nutritional quality and antigenic properties. Arch. Dis. Child. 57:842-847.

Kleber, N., I. Krause, S. Illgner, and J. Hinrichs. 2004. The antigenic response of $\beta$-lactoglobulin is modulated by thermally induced aggregation. Eur. Food Res. Technol. 219:105-110.

Kleiveland, C. R. 2015. The Impact of Food Bioactives on Health: In Vitro and Ex Vivo Models: Peripheral Blood Mononuclear Cells. Springer International Publishing, Berlin, Germany.

Kulczycki, A., G. S. Nash, M. J. Bertovich, H. D. Burack, and R. P. MacDermott. 1987. Bovine milk IgG, but not serum IgG, inhibits pokeweed mitogen-induced antibody secretion by human peripheral blood mononuclear cells. J. Clin. Immunol. 7:37-45.

Lara-Villoslada, F., M. Olivares, and J. Xaus. 2005. The balance between caseins and whey proteins in cow's milk determines its allergenicity. J. Dairy Sci. 88:1654-1660.

Li, S.-Q., J. A. Bomser, and Q. H. Zhang. 2005. Effects of pulsed electric fields and heat treatment on stability and secondary structure of bovine immunoglobulin G. J. Agric. Food Chem. 53:663-670.

Lifschitz, C., and H. Szajewska. 2015. Cow's milk allergy: Evidencebased diagnosis and management for the practitioner. Eur. J. Pediatr. 174:141-150.

Loss, G., S. Apprich, M. Waser, W. Kneifel, J. Genuneit, G. Büchele, J. Weber, B. Sozanska, H. Danielewicz, E. Horak, and R. J. van Neerven. 2011. The protective effect of farm milk consumption on childhood asthma and atopy: The GABRIELA study. J. Allergy Clin. Immunol. 128:766-773.e4.

O'Mahony, J., and P. Fox. 2013. Advanced Dairy Chemistry: Milk Proteins: Introduction and Historical Aspects. Springer, Berlin, Germany.

Opatha Vithana, N. L. 2012. A comparative study of immunomodulatory activity of deer and cow milk proteins. PhD Diss. Centre for
Food Research and Innovation, Lincoln University, Lincoln, New Zealand.

Otani, H., and I. Hata. 1995. Inhibition of proliferative responses of mouse spleen lymphocytes and rabbit Peyer's patch cells by bovine milk caseins and their digests. J. Dairy Res. 62:339-348.

Patel, H. A., H. Singh, S. G. Anema, and L. K. Creamer. 2006. Effects of heat and high hydrostatic pressure treatments on disulfide bonding interchanges among the proteins in skim milk. J. Agric. Food Chem. 54:3409-3420.

Perdijk, O., M. van Splunter, H. F. Savelkoul, R. van Neerven, and S. Brugman. 2018. Cow's milk and immune function in the respiratory tract: Potential mechanisms. Front. Immunol. 9:143.

Rahaman, T., T. Vasiljevic, and L. Ramchandran. 2015. Conformational changes of beta-lactoglobulin induced by shear, heat, and pH-Effects on antigenicity. J. Dairy Sci. 98:4255-4265.

Raphael, I., S. Nalawade, T. N. Eagar, and T. G. Forsthuber. 2015 $\mathrm{T}$ cell subsets and their signature cytokines in autoimmune and inflammatory diseases. Cytokine 74:5-17.

Rengarajan, J., S. J. Szabo, and L. H. Glimcher. 2000. Transcriptiona regulation of Th1/Th2 polarization. Immunol. Today 21:479-483.

Reyes-Díaz, A., A. F. González-Córdova, A. Hernández-Mendoza, R. Reyes-Díaz, and B. Vallejo-Cordoba. 2017. Immunomodulation by hydrolysates and peptides derived from milk proteins. Int. J. Dairy Technol. 71:1-9. https://doi.org/10.1111/1471-0307.12421.

Rosmaninho, R., and L. F. Melo. 2006. The effect of citrate on calcium phosphate deposition from simulated milk ultrafiltrate (SMUF) solution. J. Food Eng. 73:379-387.

Roth-Walter, F., M. C. Berin, P. Arnaboldi, C. R. Escalante, S. Dahan, J. Rauch, E. Jensen-Jarolim, and L. Mayer. 2008. Pasteurization of milk proteins promotes allergic sensitization by enhancing uptake through Peyer's patches. Allergy 63:882-890.

Ruiter, B., V. Tregoat, L. M'rabet, J. Garssen, C. Bruijnzeel-Koomen, E. Knol, and E. Hoffen. 2006. Characterization of T cell epitopes in as1-casein in cow's milk allergic, atopic and non-atopic children. Clin. Exp. Allergy 36:303-310.

Schade, R. P., A. G. Van Ieperen-Van Dijk, F. C. Van Reijsen, C. Versluis, J. L. Kimpen, E. F. Knol, C. A. Bruijnzeel-Koomen, and E. Van Hoffen. 2000. Differences in antigen-specific T-cell responses between infants with atopic dermatitis with and without cow's milk allergy: Relevance of T H 2 cytokines. J. Allergy Clin. Immunol. 106:1155-1162.

Tafaro, A., T. Magrone, F. Jirillo, G. Martemucci, A. D'alessandro, L. Amati, and E. Jirillo. 2007. Immunological properties of donkey's milk: Its potential use in the prevention of atherosclerosis. Curr. Pharm. Des. 13:3711-3717.

Tsitoura, D. C., and Y. Tassios. 2006. Immunomodulation: The future cure for allergic diseases. Ann. N. Y. Acad. Sci. 1088:100-115.

Vocca, I., R. B. Canani, A. Camarca, S. Ruotolo, R. Nocerino, G. Radano, A. Del Mastro, R. Troncone, and C. Gianfrani. 2011. Peripheral blood immune response elicited by beta-lactoglobulin in childhood cow's milk allergy. Pediatr. Res. 70:549-554.

Wijayanti, H. B., N. Bansal, and H. C. Deeth. 2014. Stability of whey proteins during thermal processing: A review. Compr. Rev. Food Sci. Food Saf. 13:1235-1251. 